\title{
Dehydrogenative Double C-H Bond Activation in a Germylene-Rhodium Complex
}

\author{
$\underline{\text { Sonia Bajo, María M. Alcaide, Joaquín López-Serrano, Jesús Campos* }}$
}

Instituto de Investigaciones Químicas (IIQ), Departamento de Química Inorgánica and Centro de Innovación en Química Avanzada (ORFEO-CINQA). Consejo Superior de Investigaciones Científicas (CSIC) and University of Sevilla. Avenida Américo Vespucio 49, 41092 Sevilla (Spain).

\begin{abstract}
Transition metal tetrylene complexes offer great opportunities for molecular cooperation due to the ambiphilic character of the group 14 element. Here we focus on the coordination of germylene $\left[\left(\mathrm{Ar}^{\mathrm{Mes} 2}\right)_{2} \mathrm{Ge}\right]_{(\mathrm{Ar}}{ }^{\mathrm{Mes}}$ $\left.=\mathrm{C}_{6} \mathrm{H}_{3}-2,6-\left(\mathrm{C}_{6} \mathrm{H}_{2}-2,4,6-\mathrm{Me}_{3}\right)_{2}\right)$ to $[\mathrm{RhCl}(\mathrm{COD})]_{2}(\mathrm{COD}=1,5$-cyclooctadinene $)$, which yields a neutral germyl complex in which the rhodium center exhibits both $\eta^{6}$ - and $\eta^{2}$-coordination to two mesityl rings in an unusual pincertype structure. Chloride abstraction from this species triggers a singular dehydrogenative double $\mathrm{C}-\mathrm{H}$ bond activation across the Ge/Rh motif. We have isolated and fully characterized three rhodium-germyl species associated to three $\mathrm{C}-\mathrm{H}$ cleavage events along this process. The reaction mechanism has been further investigated by computational means, supporting the key cooperative action of rhodium and germanium centers.
\end{abstract}

Transition metal complexes bearing ambiphilic ligands that combine both electron donor and acceptor groups have attracted a great deal of attention in recent times. ${ }^{1-3}$ In this regard, heavier tetrylenes $\left(: \mathrm{ER}_{2} ; \mathrm{E}=\mathrm{Si}, \mathrm{Ge}, \mathrm{Sn}, \mathrm{Pb}\right)$ offer unique opportunities as single-site ambiphiles ( $\sigma$-donating lone pair and empty p orbital), revealing unusual coordination modes and reactivity..$^{-12}$ Moreover, they represent the prospects of new avenues for transition metal/P-element cooperation. ${ }^{13-25}$ However, the coordination chemistry of tetrylenes remains considerably less explored than their lighter carbene congeners, in no little part due to reduced stability. To overcome this limitation base-stabilized tetrylenes have been explored and their complexes have found relevance in catalysis. ${ }^{26-29}$ Nonetheless, quenching their Z-type character by inter- or intramolecular bases hampers their potential to actively cooperate with the transition metal in bond activation processes.

Steric shielding around the tetrel site has also been widely exploited as a strategy to provide kinetic stabilization, being terphenyl $\left(\mathrm{C}_{6} \mathrm{H}_{3}-2,6-\mathrm{Ar}_{2}\right)$ substituents among the preferred choice. ${ }^{30}$ In fact, coordination of terphenyl-stabilized tetrylenes to transition metals has already provided compelling results, ${ }^{31-37}$ revealing the tunable donor/acceptor nature of the group 14 element ${ }^{38,39}$ and the realization of its highly dynamic binding capacity. ${ }^{40-45}$ For instance, the interconversion with tetrylidyne $(\mathrm{M}=\mathrm{E}-\mathrm{R})$ and tetryl $\left(\mathrm{M}-\mathrm{ER}_{3}\right)$ forms drastically modify the bonding with the transition metal and its stereoelectronic properties, producing reactive unsaturated sites amenable for divergent reactivity. ${ }^{46}$ In this study, we report the formation of a rhodium germylene/germyl complex based on the bis-terphenyl $\left[\left(\mathrm{Ar}^{\mathrm{Mes} 2}\right)_{2} \mathrm{Ge}\right]\left(\mathrm{Ar}^{\mathrm{Mes}}=\mathrm{C}_{6} \mathrm{H}_{3}-2,6-\left(\mathrm{C}_{6} \mathrm{H}_{2}-\right.\right.$ $\left.\left.2,4,6-\mathrm{Me}_{3}\right)_{2}\right)^{47}$ that promotes a unique intramolecular dehydrogenative double $\mathrm{C}-\mathrm{H}$ bond activation process in which the germanium center reversibly rearranges from germylene to germyl forming $\mathrm{Ge}-\mathrm{Cl}, \mathrm{Ge}-\mathrm{H}$ and $\mathrm{Ge}-\mathrm{C}$ bonds in concert with the rhodium site.

Heating an equimolar toluene solution of $[\mathrm{RhCl}(\mathrm{COD})]_{2}(\mathrm{COD}=1,5$-cyclooctadinene $)$ and $\left[\left(\mathrm{Ar}^{\mathrm{Mes} 2}\right)_{2} \mathrm{Ge}\right.$ : $]$ at $80{ }^{\circ} \mathrm{C}$ for twelve hours afforded the formation of germyl rhodium complex 1, which precipitated from the reaction media as a dark orange solid in $86 \%$ yield (Scheme 1 ). The release of COD, clearly identified by ${ }^{1} \mathrm{H}$ NMR, is accompanied by $\eta^{6}$-coordination of the $\pi$-system of one of the flanking aryl rings of a terphenyl substituent..$^{40,43,48-51}$ This is consistent with a somewhat deshielded ${ }^{1} \mathrm{H}$ NMR resonance at $5.16 \mathrm{ppm}(2 \mathrm{H})$ that contrasts with the corresponding resonance in [( $\left.\left.\mathrm{Ar}^{\mathrm{Mes} 2}\right)_{2} \mathrm{Ge}:\right]$ found at $6.76 \mathrm{ppm}$. The associated ${ }^{13} \mathrm{C}\left\{{ }^{1} \mathrm{H}\right\}$ NMR signal resonates at $119.9 \mathrm{ppm}$ (c.f. 129.0 ppm in [( $\left.\left.\left.\mathrm{Ar}^{\mathrm{Mes} 2}\right)_{2} \mathrm{Ge}:\right]\right)$ and exhibits scalar coupling to ${ }^{103} \mathrm{Rh}\left(\mathrm{d},{ }^{1} J_{\mathrm{CRh}}=9 \mathrm{~Hz}\right)$, in line with the proposed coordination. The molecular formulation of $\mathbf{1}$ was ascertained by X-ray diffraction studies (Figure 1), evidencing insertion of the germylene into the $\mathrm{Rh}-\mathrm{Cl}$ bond, as previously observed in other rhodium/germylene systems. ${ }^{52-55}$ Besides, the rhodium center is $\eta^{2}$-coordinated to a lateral ring of the alternate terphenyl fragment $\left(\mathrm{Rh} 1-\mathrm{C}_{31}=\mathbf{2 . 1 5 3 ( 2 )}\right.$ and Rh1 $-\mathrm{C}_{32}=\mathbf{2 . 1 9 4 ( 2 )} \AA$ ), thus resembling an unusual type of pincer-type coordination of the germyl moiety. 


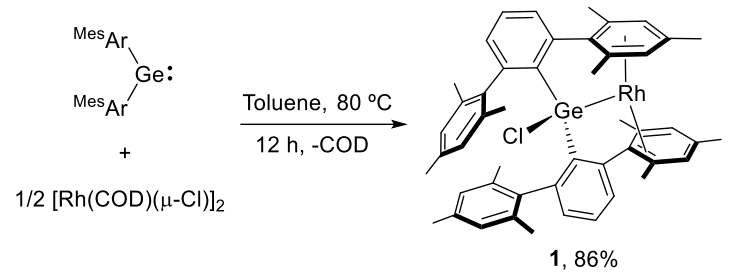

Scheme 1. Synthesis of germyl rhodium complex 1.

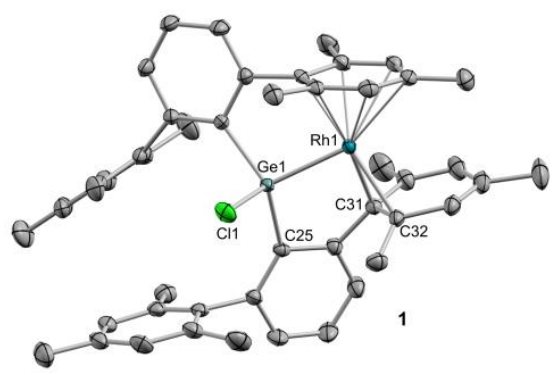

Figure 1. ORTEP diagram of 1. Hydrogen atoms are excluded for clarity, and thermal ellipsoids are set at 50\% probability.

To investigate bond activation processes through $\mathrm{Ge} / \mathrm{Rh}$ bimetallic cooperation ${ }^{56}$ we first targeted chloride abstraction from 1. Addition of $\mathrm{AgNTf}_{2}\left(\mathrm{NTf}_{2}=\right.$ triflimidate $\left.=\left[\mathrm{N}\left(\mathrm{SO}_{2} \mathrm{CF}_{3}\right)_{2}\right]^{-}\right)$surprisingly led to the withdrawal of a hydride, inferred by a distinctive ${ }^{1} \mathrm{H}$ NMR resonance at $0.87 \mathrm{ppm}\left(\mathrm{t},{ }^{1} J_{\mathrm{HAg}}=7 \mathrm{~Hz}\right)$ attributable to $\left[\mathrm{AgH}\left(\mathrm{NTf}_{2}\right)\right]_{\mathrm{n}}{ }^{57,58}$ readily generating germyl-rhodium $\mathbf{2}$ in good yields (Scheme 2). In fact, an analogous process instantly takes place by treatment of 1 with trityl salt $\left[\mathrm{CPh}_{3}\right]\left[\mathrm{B}\left(\mathrm{C}_{6} \mathrm{~F}_{5}\right)_{4}\right]$, with concomitant formation of $\mathrm{CHPh}_{3}$. The activation of one benzylic $\mathrm{C}-\mathrm{H}$ bond originates a characteristic $\mathrm{AB}$ system in the ${ }^{1} \mathrm{H}$ NMR spectra due to the diastereotopic $\mathrm{Rh}-$ $\mathrm{CH}_{2}$ protons, with slightly broad signals at 3.93 and $1.36 \mathrm{ppm}$. Their corresponding ${ }^{13} \mathrm{C}\left\{{ }^{1} \mathrm{H}\right\}$ NMR peak resonates at $42.3 \mathrm{ppm}\left(\mathrm{d},{ }^{1} J_{\mathrm{CRh}}=12 \mathrm{~Hz}\right)$.

To our delight, treatment of 1 with $\mathrm{NaBAr}^{\mathrm{F}}$ immediately effects the initially targeted chloride abstraction. The resulting compound $\mathbf{3}$ is spectroscopically similar to chloride-containing $\mathbf{2}$. Thus, an analogous $\mathrm{AB}$ pattern is present, but accompanied by an additional resonance at 6.02 due to a $\mathrm{Ge}-\mathrm{H}$ terminus. Interestingly, addition of two equivalents of $\left(\mathrm{PMe}_{2} \mathrm{Ar}^{\mathrm{Dipp} 2}\right) \mathrm{Au}\left(\mathrm{NTf}_{2}\right)^{59,60}\left(\mathrm{Ar}^{\mathrm{Dipp} 2}=\mathrm{C}_{6} \mathrm{H}_{3}-2,6-\left(\mathrm{C}_{6} \mathrm{H}_{3}-2,6-{ }^{i} \mathrm{Pr}_{2}\right)_{2}\right)$ to precursor 1 generates as well compound 3 along with the chloride-bridged digold species $\left[\left(\mathrm{PMe}_{2} \mathrm{Ar}^{\mathrm{Dipp} 2}\right)_{2} \mathrm{Au}_{2}(\mu-\mathrm{Cl})\right]$. This contrasts with the aforementioned inability of silver salts to abstract the chloride substituent. Besides, we found slight NMR spectroscopic differences for the products derived from reactions of 1 with $\mathrm{AgNTf}_{2} v s\left[\mathrm{CPh}_{3}\right]\left[\mathrm{B}\left(\mathrm{C}_{6} \mathrm{~F}_{5}\right)_{4}\right]$ and those with $\mathrm{NaBAr}^{\mathrm{F}}$ vs $\left(\mathrm{PMe}_{2} \mathrm{Ar}^{\mathrm{Dipp} 2}\right) \mathrm{Au}\left(\mathrm{NTf}_{2}\right)$ that we attribute to counteranion effects (see Figure $\mathrm{S} 1$ ).

It is clear from these latter experiments that yield compound $\mathbf{3}$ that the formation of a transient cationic germanium site is central for the facile activation of a benzylic $\mathrm{C}-\mathrm{H}$ bond, which does not take place from $\mathbf{1}$ even under harsh conditions $\left(100^{\circ} \mathrm{C}, 48 \mathrm{~h}\right)$. In fact, germylenes are highly reluctant to insertion into $\mathrm{C}-\mathrm{H}$ bonds $\mathrm{s}^{61}$ and the only other example of terphenyl benzylic $\mathrm{C}-\mathrm{H}$ bond activation in a tetrylene relied on the use of an extremely $\sigma$-donating boryl ligand, ${ }^{62}$ while herein the cooperative participation of both Ge and Rh sites is crucial. The mechanism by which compound $\mathbf{3}$ is formed has been investigated and shall be discussed along these lines. 


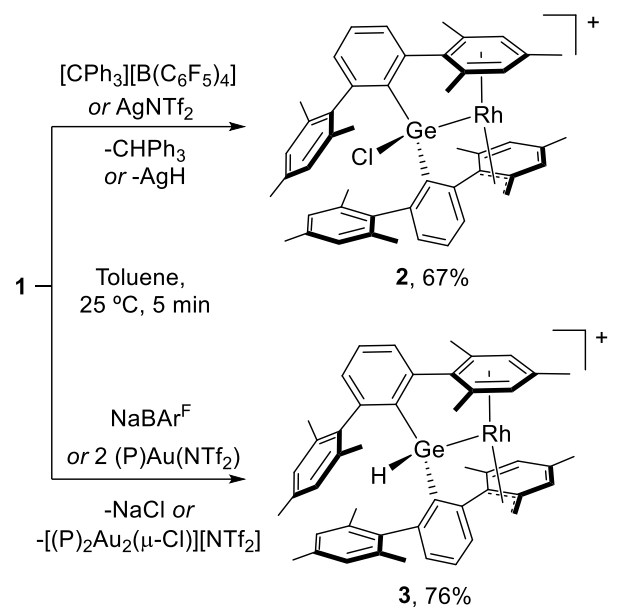

Scheme 2. Synthesis of compounds 2 and 3 from germyl-rhodium 1 by hydride and chloride abstraction, respectively.

Compounds $\mathbf{2}$ and $\mathbf{3}$ were unequivocally characterized by X-ray diffraction as pseudoallylic species (Figure 2 and $\mathrm{S} 2$ ), with $\eta^{6}$-coordination to the alternate terphenyl substituent being retained. Pseudoallylic coordination is defined by average $\mathrm{Rh}-\mathrm{C}$ bond distances of $2.28\left(\mathrm{CH}_{2}\right), 2.13\left(\mathrm{C}_{\text {orto }}\right)$ and $2.18 \AA\left(\mathrm{C}_{\mathrm{ipso}}\right)$, while other geometric parameters are comparable to those of $\mathbf{1}$.
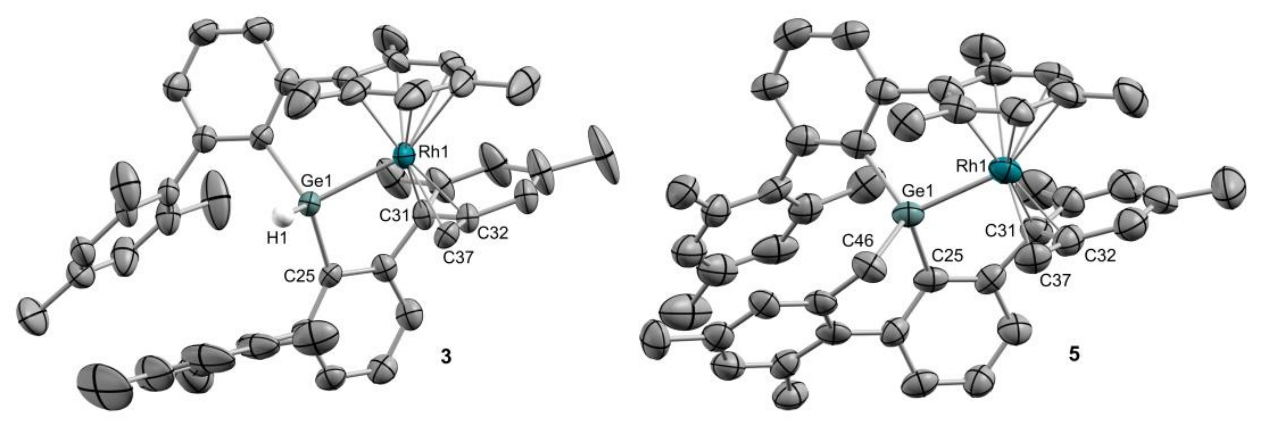

Figure 2. ORTEP diagrams of $\mathbf{3}$ and 5. Counteranions, solvent molecules and most hydrogen atoms are excluded for clarity, and thermal ellipsoids are set at 50\% probability.

Heating compound 3 in benzene or toluene solution for seven hours results in its quantitative conversion into 4 , characterized by a distinctive low-frequency ${ }^{1} \mathrm{H}$ NMR signal at $-18.12 \mathrm{ppm}\left({ }^{1} J_{\mathrm{HRh}}=21.6 \mathrm{~Hz}\right)$ due to a hydride ligand bound to rhodium (Scheme 3). A thorough analysis of multinuclear mono and bidimensional NMR spectra reveals that only one of the benzylic positions of the mesityl rings is activated, although it has migrated to the germanium center. This double hydride/methylene migration between germanium and rhodium represents a rare example of the potential for cooperation in this type of hybrid main group/transition metal complexes. The formation of $\mathbf{4}$ most likely implies accessing a reactive germylene intermediate as $\mathbf{A}$ in Scheme 3, in turn the parent species from which the initial $\mathrm{C}-\mathrm{H}$ activation to yield $\mathbf{3}$ after chloride abstraction would take place. 


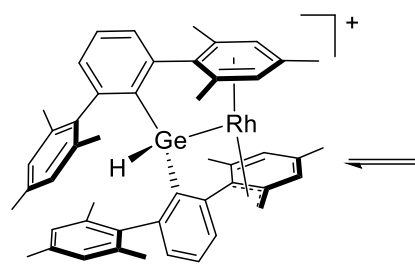

3

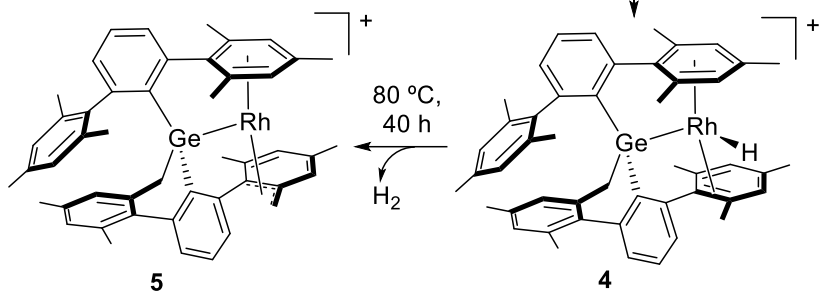

Scheme 3. Formation of compounds 4 and 5 by stepwise double hydride/methylene migration followed by dehydrogenative $\mathrm{C}-\mathrm{H}$ bond activation.

The appearance of 4 was accompanied by minute amounts $(<5 \%)$ of another species $(5)$ for which the hydride ligand vanishes from the ${ }^{1} \mathrm{H}$ NMR spectrum. Further heating for 40 hours results in clean and complete conversion into 5. This compound conserves the $\mathrm{AB}$ system observed by ${ }^{1} \mathrm{H}$ NMR in complex 4, with two signals at 2.50 (d, ${ }^{3} J_{\mathrm{HRh}}=14.4 \mathrm{~Hz}$ ) and $2.06 \mathrm{ppm}$, while also incorporates a related AB pattern (broad signals at 3.37 and $0.54 \mathrm{ppm}$ ) analogous to that found in compounds 2 and 3. This suggests that two benzylic positions have now been activated with concomitant release of dihydrogen. This is in accordance with a total number of ten resonances accounting for three protons each between 1.24 and $2.21 \mathrm{ppm}$ due to the methyl groups. This assumption was corroborated by Xray diffraction studies (Figure 2), where one of the terphenyl substituents is doubly cyclometalated to both germanium and rhodium in $\eta^{1}$ and $\eta^{3}$-fashion, respectively, a transformation that finds no precedent in the chemistry of tetrylenes.

Mechanistic understanding on this dehydrogenative double $\mathrm{C}-\mathrm{H}$ bond activation is central to further explore the cooperative potential of this kind of tetrylene-transition metal systems. Investigation of the formation of species 35 by DFT methods (SMD- $\omega B$ 97XD/6-31g(d,p)/SDD level; see the Supporting Information for details) were carried out starting from the cationic germylene-rhodium $\mathbf{A}$ that results from elimination of the chloride atom in 1 (Figure 3 ). The species retains the coordination environment around rhodium in $\mathbf{1}$, whereas the expected trigonal planar geometry is found around the germanium, and the $\mathrm{Ge}-\mathrm{Rh}$ distance is $2.25 \AA$. The calculations favor initial $\mathrm{C}-\mathrm{H}$ activation at rhodium, which occurs through a low energy barrier $(\Delta G$ from $\mathbf{A})$ of ca. $10 \mathrm{kcal} \cdot \mathrm{mol}^{-1}$ to afford a new germyl intermediate, $\mathbf{B}$, featuring a formally $\mathrm{Rh}$ (III) hydride moiety. Species $\mathbf{3}$ would in turn result from hydride migration from $\mathrm{Rh}$ to $\mathrm{Ge}$, having the transformation an overall barrier of ca $16 \mathrm{kcal} \cdot \mathrm{mol}^{-1}$ from A. AIM and NBO analyses (SMD- $\omega$ B97XD/Def2TZVP level) were used to probe the germanium-rhodium interaction throughout the reaction pathway, showing and increase in the double bond character of the $\mathrm{Ge}-\mathrm{Rh}$ bond in $\mathbf{A}$, as a result of $\mathrm{Rh}$ to Ge back donation, which decreases in $\mathbf{B}$ as expected (see the SI for details). 


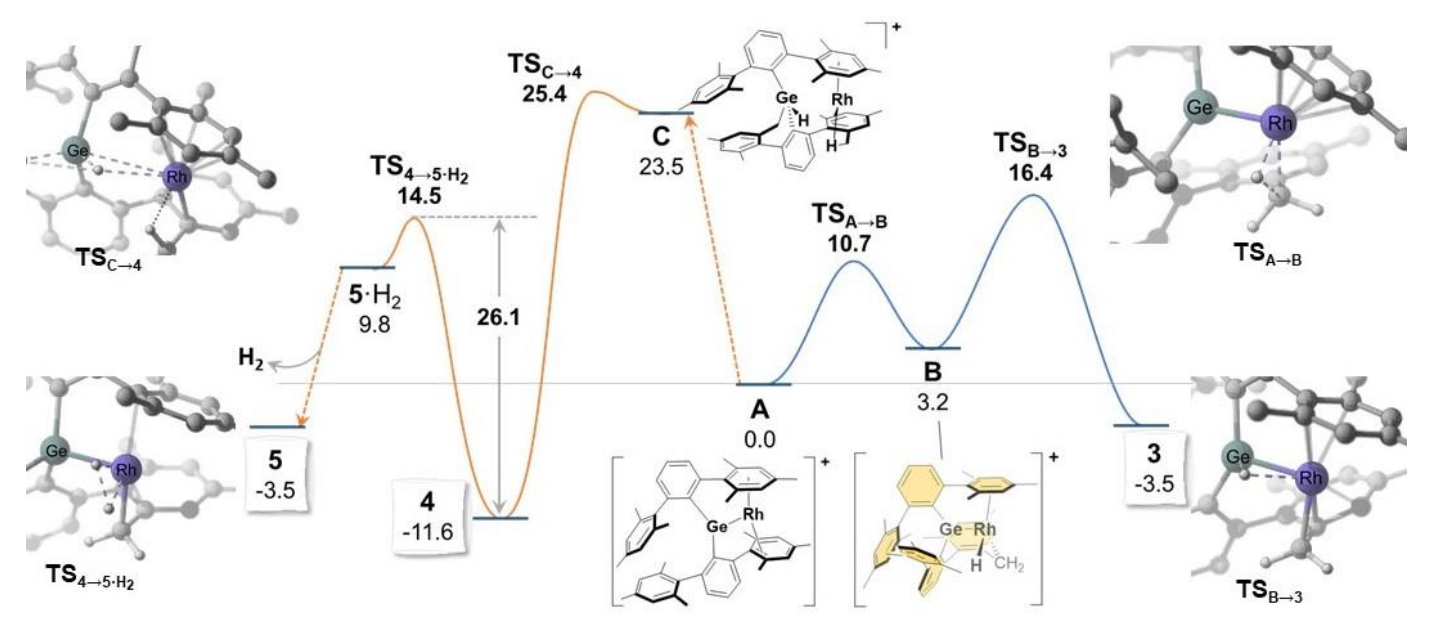

FIGURE 3. $\Delta G^{\mathrm{sol}}$ profile $\left(\mathrm{kcal} \cdot \mathrm{mol}^{-1}\right.$; benzene) for the formation of $\mathbf{3}$ and $\mathbf{4}$ from intermediate $\mathbf{A}$, as well $\mathrm{C}-\mathrm{H}$ dehydrogenative activation towards $\mathbf{5}$ and calculated geometries of transition states.

Formation of $\mathbf{4}$ and $\mathbf{5}$ from $\mathbf{3}$ under forcing conditions implies accessing the reacting germylene intermediate $\mathbf{A}$, from which the addition product, the germyl $\mathbf{C}$, may be accessible, located $23.5 \mathrm{kcal} \cdot \mathrm{mol}^{-1}$ above $\mathbf{A}$. Then 4 would result from $\mathrm{H}$ migration from $\mathrm{Ge}$ to $\mathrm{Rh}$, which is predicted to be almost barrierless. This species is located -11.6 $\mathrm{kcal} \cdot \mathrm{mol}^{-1}$ below $\mathbf{A}$ in agreement with experiments. Finally, $\mathrm{H}_{2}$ release implies a third $\mathrm{C}-\mathrm{H}$ activation event, this time again at the rhodium center, which has a barrier of ca $26 \mathrm{kcal} \cdot \mathrm{mol}^{-1}$ from 4 .

In summary, the reactivity studies described in the foregoing sections constitute a remarkable illustration of the cooperative potential of transition metal tetrylenes. Chloride abstraction from a rhodium-embraced germyl compound initiates a highly unusual series of bond breaking events that result in the double $\mathrm{C}-\mathrm{H}$ bond activation of two benzylic positions with concomitant release of dihydrogen. Computational studies provide a mechanistic picture for the above transformation, emphasizing the key cooperative action between rhodium and germanium. The process involves up to three $\mathrm{C}-\mathrm{H}$ bond cleavage steps, as well as reversible hydride migration and formal hydrocarbyl migration between germanium and rhodium. These observations highlight the prospects for cooperative bond activation and catalysis of transition metal tetrylenes, which may surpass the more widely explored base-stabilized tetrylenes as ligands for transition metals.

Supporting Information. Synthesis and characterization of new compounds, X-ray diffraction information, computational details and NMR spectra.

\section{Acknowledgment}

This work has been supported by the European Research Council (ERC Starting Grant, CoopCat, 756575) and Junta de Andalucia (P18-FR-4688). The use of computational facilities at the Supercomputing Centre of Galicia (CESGA) and the Centro de Servicios de Informatica y Redes de Comunicaciones (CSIRC), University of Granada are acknowledged.

\section{References}

(1) Devillard, M.; Bouhadir, G.; Bourissou, D. Cooperation between Transition Metals and Lewis Acids: A Way To Activate $\mathrm{H}_{2}$ and $\mathrm{H}-\mathrm{E}$ bonds. Angew. Chem. Int. Ed. 2015, 54, 730-732.

(2) Bouhadir, G.; Bourissou, D. Complexes of ambiphilic ligands: reactivity and catalytic applications. Chem. Soc. Rev. 2016, 45, 1065-1079.

(3) You, D.; Gabbaï, F. P. Tunable $\square$-Accepting, Z-Type Ligands for Organometallic Catalysis. Trends in Chemistry 2019, 1, 485- 496. 
(4) Hicks, J.; Hadlington, T. J.; Schenk, C.; Li, J.; Jones, C. Utilizing Steric Bulk to Stabilize Molybdenum Aminogermylyne and Aminogermylene Complexes. Organometallics 2013, 32, 323-329.

(5) Inomata, K.; Watanabe, T.; Tobita, H. Cationic Metallogermylene and Dicationic Dimetallodigermenes: Synthesis by Chloride Abstraction from N-Heterocyclic Carbene-Stabilized Chlorometallogermylenes. J. Am. Chem. Soc. 2014, 136, 14341-14344.

(6) Filippou, A. C.; Baars, B.; Chernov, O.; Lebedev, Y. N.; Schnakenburg, G. Silicon-Oxygen Double Bonds: A Stable Silanone with a Trigonal-Planar Coordinated Silicon Center. Angew. Chem. Int. Ed. 2014, 53, 565-570.

(7) Inomata, K.; Watanabe, T.; Miyazaki, Y.; Tobita, H. Insertion of a Cationic Metallogermylene into E-H Bonds $(\mathrm{E}=\mathrm{H}, \mathrm{B}, \mathrm{Si})$. J. Am. Chem. Soc. 2015, 137, 11935-11937.

(8) Gendy, C.; Mansikkamäki, A.; Valjus, J.; Heidebrecht, J.; Hui, P. C.-Y.; Bernard, G. M.; Tuononen, H. M.; Wasylishen, R. E.; Michaelis, V. K.; Roesler, R. Nickel as a Lewis Base in a T-Shaped Nickel(0) Germylene Complex Incorporating a Flexible Bis(NHC) Ligand. Angew. Chem. Int. Ed. 2019, 58, $154-158$.

(9) Watanabe, T.; Kasai, Y.; Tobita, H. A Nickel Complex Containing a Pyramidalized, Ambiphilic Pincer Germylene Ligand. Chem. Eur. J. 2019, 25, $13491-13495$.

(10) Feng, Z.; Jiang, Y.; Ruan, H.; Zhao, Y.; Tan, G.; Zhang, L.; Wang, X. A diamidinatogermylene as a Z-type ligand in a nickel(0) complex. Dalton Trans. 2019, 48, 14975-14978.

(11) Dhungana, T. P.; Hashimoto, H.; Ray, M.; Tobita, H. Synthesis of a Molybdenum Hydrido(hydrogermylene) Complex and Its Conversion to a Germylyne Complex: Another Route through Dehydrogenation with Nitriles. Organometallics 2020, 39, 4350-4361.

(12) Keil, P.M.; Szilvasi, T.; Hadlington, T. J. Reversible metathesis of ammonia in an acyclic germylene-Ni ${ }^{0}$ complex. DOI: 10.1039/d1sc00450f.

(13) Litz, K. E.; Bender IV, J. E.; Kampf, J. W.; Holl, M. M. B. Transition Metal Germylene Complexes as Hydrogenation Catalysts: The Synthesis of a Rare Bis(amino)germane. Angew. Chem. Int. Ed. Engl. 1997, 36, 496-498.

(14) Watanabe, T.; Hashimoto, H.; Tobita, H. Hydrido(hydrosilylene)tungsten Complexes with Strong Interactions between the Silylene and Hydrido Ligands. Angew. Chem. Int. Ed. 2004, 43, $218-221$.

(15) Watanabe, T.; Hashimoto, H.; Tobita, H. Stoichiometric Hydrosilylation of Nitriles with Hydrido(hydrosilylene)tungsten Complexes: Formation of W-Si-N Three-Membered Ring Complexes and Their Unique Thermal Behaviors. J. Am. Chem. Soc. 2006, 128, 2176-2177.

(16) Watanabe, T.; Hashimoto, H.; Tobita, H. Reactions of Hydrido(hydrosilylene)tungsten Complexes with $\alpha, \beta$ Unsaturated Carbonyl Compounds: Selective Formation of ( $\eta^{3}$-Siloxyallyl)tungsten Complexes. J. Am. Chem. Soc. 2007, 129, 11338-11339.

(17) Hayes, P. G.; Gribble, C. W.; Waterman, R.; Tilley, T. D. A Hydrogen-Substituted Osmium Stannylene Complex: Isomerization to a Metallostannylene Complex via an Unusual $\alpha$-Hydrogen Migration from Tin to Osmium J. Am. Chem. Soc. 2009, 131, 4606-4607.

(18) Suzuki, E.; Komuro, T.; Kanno, Y.; Tobita, H. ( $\eta^{3}-\alpha$-Silabenzyl)tungsten Complexes: An Isolable Intermediate for Interconversion between a Silylene Complex and a Silyl Complex through 1,2-Aryl Migration. Organometallics 2013, 32, 748-751. (19) Komuro, T.; Kanno, Y.; Tobita, H. Synthesis, Structure, and Reactions of a $\left(\eta^{3}-\alpha\right.$-silabenzyl)molybdenum Complex: A Synthetic Equivalent of a Coordinatively Unsaturated Silyl Complex Organometallics 2013, 32, 2795-2803.

(20) Liu, H.-J.; Guihaumé, J.; Davin, T.; Raynaud, C.; Eisenstein; O.; Tilley, T. D. 1,2-Hydrogen Migration to a Saturated Ruthenium Complex via Reversal of Electronic Properties for Tin in a Stannylene-to-Metallostannylene Conversion. J. Am. Chem. Soc. 2014, 136, 13991-13994.

(21) Dhungana, T. P.; Hashimoto, H.; Tobita, H. An iron germylene complex having Fe-H and Ge-H bonds: synthesis, structure and reactivity. Dalton Trans. 2017, 46, 8167-8179.

(22) Lebedev, Y. N.; Das, U.; Schnakenburg, G.; Filippou, A. C. Coordination Chemistry of [E(Idipp)] ${ }^{2+}$ Ligands $(\mathrm{E}=\mathrm{Ge}, \mathrm{Sn})$ : Metal Germylidyne $\left[\mathrm{Cp} *(\mathrm{CO})_{2} \mathrm{~W}-\mathrm{Ge}(\mathrm{Idipp})\right]^{+}$and Metallotetrylene $\left[\mathrm{Cp} *(\mathrm{CO})_{3} \mathrm{~W}-\mathrm{E}(\mathrm{Idipp})\right]^{+} \mathrm{Cations}$. Organometallics 2017, 36, 1530-1540.

(23) Price, J. S.; Emslie, D. J. H.; Britten, J. F. Manganese Silylene Hydride Complexes: Synthesis and Reactivity with Ethylene to Afford Silene Hydride Complexes. Angew. Chem. 2017, 129, 6319-6323.

(24) Lee, V. Y.; Horiguchi, S.; Gapurenko, O. A.; Minyaev, R. M.; Minkin, V. I.; Gornitzka, H.; Sekiguchi, A. [2+2] Cycloadduct of Titanium Silylidene and Benzonitrile. Eur. J. Inorg. Chem. 2019, 4224-4227.

(25) Cabeza, J. A.; García-Álvarez, P.; Laglera-Gándara, C. J.; Pérez-Carreño, E. A Z-type PGeP pincer germylene ligand in a T-shaped palladium(0) complex. Chem. Commun. 2020, 56, 14095-14097.

(26) Asay, M.; Jones, C.; Driess, M. N-Heterocyclic Carbene Analogues with Low-Valent Group 13 and Group 14 Elements: Syntheses, Structures, and Reactivities of a New Generation of Multitalented Ligands. Chem. Rev. 2011, 111, 354-396. 
(27) Álvarez-Rodríguez, L.; Cabeza, J. A.; García-Álvarez, P.; Polo, D. The transition-metal chemistry of amidinatosilylenes, -germylenes and -stannylenes. Coordination Chemistry Reviews 2015, 300, 1-28.

(28) Zhou, Y.-P.; Driess, M. Isolable Silylene Ligands Can Boost Efficiencies and Selectivities in Metal-Mediated Catalysis. Angew. Chem. Int. Ed. 2019, 58, 3715-3728.

(29) Cabeza, J. A.; García-Álvarez, P.; Laglera-Gándara, C. J. The Transition Metal Chemistry of PGeP and PSnP Pincer Heavier Tetrylenes. Eur. J. Inorg. Chem. 2020, 784-795.

(30) Power, P. P. Reactions of Heavier Main-Group Compounds with Hydrogen, Ammonia, Ethylene and Related Small Molecules. The Chemical Record 2011, 12, 238-255.

(31) Lei, H.; Guo, J.-D.; Fettinger, J. C.; Nagase, S.; Power, P. P. Synthesis, Characterization, and CO Elimination of Ferrio-Substituted Two-Coordinate Germylenes and Stannylenes. Organometallics 2011, 30, 6316-6322.

(32) Filippou, A. C.; Ghana, P.; Chakraborty, U.; Schnakenburg, G. Manganese-Tin Triple Bonds: A New Synthetic Route to the Manganese Stannylidyne Complex Cation trans- $\left[\mathrm{H}(\mathrm{dmpe})_{2} \mathrm{Mn}-\mathrm{Sn}\left(\mathrm{C}_{6} \mathrm{H}_{3}-2,6-\mathrm{Mes}_{2}\right)\right]^{+}(\mathrm{dmpe}=$ $\mathrm{Me}_{2} \mathrm{PCH}_{2} \mathrm{CH}_{2} \mathrm{PMe}_{2}$, Mes = 2,4,6-Trimethylphenyl). J. Am. Chem. Soc. 2013, 135, 11525-11528.

(33) Sindlinger, C. P.; Wesemann, L. Dimeric platinum-stannylene complexes by twofold ligand transfer from an NHC adduct to an organotin(II) hydride. Chem. Commun. 2015, 51, 11421-11424.

(34) Hoidn, C. M.; Rödl, C.; McCrea-Hendrick, M. L.; Block, T.; Pöttgen, R.; Ehlers, A. W.; Power, P. P.; Wolf, R. Synthesis of a Cyclic $\mathrm{Co}_{2} \mathrm{Sn}_{2}$ Cluster Using a Co Synthon. J. Am. Chem. Soc. 2018, 140, 13195-13199.

(35) Frisch, P.; Inoue, S. Coinage metal complexes of NHC-stabilized silyliumylidene ions. Chem. Commun. 2018, 54, 13658-13661.

(36) Maudrich, J.-J.; Widemann, M.; Diab, F.; Kern, R. H.; Sirsch, P.; Sindlinger, C. P.; Schubert, H.; Wesemann, L. Hydridoorganostannylene Coordination: Group 4 Metallocene Dichloride Reduction in Reaction with Organodihydridostannate Anions. Chem. Eur.J. 2019, 25, $16081-16087$.

(37) Bajo, S.; Alcaide, M. M.; López-Serrano, J.; Campos, J. Structural Snapshots of $\square$-Arene Bonding in a Gold Germylene Cation. Chem. Eur.J. 2020, 26, $15519-15523$.

(38) Krebs, K. M.; Freitag, S.; Schubert, H.; Gerke, B.; Pöttgen, R.; Wesemann, L. Chemistry of Stannylene-Based Lewis Pairs: Dynamic Tin Coordination Switching Between Donor and Acceptor Character. Chem. Eur. J. 2015, 21, 4628-4638.

(39) Krebs, K. M.; Freitag, S.; Maudrich, J.-J.; Schubert, H.; Sirsch, P.; Wesemann, L. Coordination chemistry of stannylene-based Lewis pairs - insertion into $\mathrm{M}-\mathrm{Cl}$ and $\mathrm{M}-\mathrm{C}$ bonds. From base stabilized stannylenes to bidentate ligands. Dalton Trans. 2018, 47, 83-95.

(40) Pu, L.; Twamley, B.; Haubrich, S. T.; Olmstead, M. M.; Mork, B. V.; Simons, R. S.; Power, P. P. Triple Bonding to Germanium: Characterization of the Transition Metal Germylynes $\left(\eta^{5}-\mathrm{C}_{5} \mathrm{H}_{5}\right)(\mathrm{CO})_{2} \mathrm{M}-\mathrm{Ge}_{-} \mathrm{C}_{6} \mathrm{H}_{3}-2,6-\mathrm{Mes}_{2}(\mathrm{M}=$ Mo, W; Mes $\left.=-\mathrm{C}_{6} \mathrm{H}_{2}-2,4,6-\mathrm{Me}_{3}\right)$ and $\left(\eta^{5}-\mathrm{C}_{5} \mathrm{H}_{5}\right)(\mathrm{CO})_{2} \mathrm{M}-\mathrm{Ge}_{-} \mathrm{C}_{6} \mathrm{H}_{3}-2,6-\mathrm{Trip}_{2}\left(\mathrm{M}=\mathrm{Cr}, \mathrm{Mo}, \mathrm{W}\right.$; Trip $=-\mathrm{C}_{6} \mathrm{H}_{2}-2,4,6-\mathrm{i}-$ $\left.\mathrm{Pr}_{3}\right)$ and the Related Single Bonded Metallogermylenes $\left(\eta^{5}-\mathrm{C}_{5} \mathrm{H}_{5}\right)(\mathrm{CO})_{3} \mathrm{M}-\mathrm{Ge}-\mathrm{C}_{6} \mathrm{H}_{3}-2,6-\mathrm{Trip}_{2}(\mathrm{M}=\mathrm{Cr}, \mathrm{W}) . J . A m$. Chem. Soc. 2000, 122, 650-656.

(41) Filippou, A. C.; Weidemann, N.; Philippopoulos, A. I.; Schnakenburg, G. Activation of Aryl Germanium(II) Chlorides by $\left[\mathrm{Mo}\left(\mathrm{PMe}_{3}\right)_{6}\right]$ and $\left[\mathrm{W}\left(\square^{2}-\mathrm{CH}_{2} \mathrm{PMe}_{2}\right) \mathrm{H}\left(\mathrm{PMe}_{3}\right)_{4}\right]$ : A New Route to Metal-Germanium Triple Bonds. Angew. Chem. Int. Ed. 2006, 45, 5987-5991.

(42) Matsumoto, T.; Nakaya, Y.; Itakura, N.; Tatsumi, K. A Functional Hydrogenase Model: Reversible Interconversion of $\mathrm{H}_{2}$ and $\mathrm{H}_{2} \mathrm{O}$ by a Hydroxo/Sulfido-Bridged Dinuclear Ruthenium-Germanium Complex. J. Am. Chem. Soc. 2008, 130, 2458-2459.

(43) Matsumoto, T.; Itakura, N.; Nakaya, Y.; Tatsumi, K. Dihydrogen activation by sulfido-bridged dinuclear Ru/Ge complexes: insight into the [NiFe] hydrogenase unready state. Chem. Commun. 2011, 47, 1030-1032.

(44) Smith, P. W.; Handford, R. C.; Tilley, T. D. Heavy Tetrel Complexes of Ru Featuring Ru=E(R)X and Ru-E$\mathrm{R}(\mathrm{E}=\mathrm{Sn}, \mathrm{Pb})$ Linkages. Organometallics 2019, 38, 4060-4065.

(45) Widemann, M.; Eichele, K.; Schubert, H.; Sindlinger, C. P.; Klenner, S.; Pöttgen, R.; Wesemann, L. Synthesis and Hydrogenation of Heavy Homologues of Rhodium Carbynes: [ $\left.\left(\mathrm{Me}_{3} \mathrm{P}\right)_{2}\left(\mathrm{Ph}_{3} \mathrm{P}\right) \mathrm{Rh} / \mathrm{E}-\mathrm{Ar} *\right](\mathrm{E}=\mathrm{Sn}, \mathrm{Pb})$. .

(46) Smith, P. W.; Tilley, T. D. Base-Free Iron Hydrosilylene Complexes via an $\alpha$-Hydride Migration that Induces Spin Pairing. J. Am. Chem. Soc. 2018, 140, 3880-3883.

(47) Simons, R. S.; Pu, L.; Olmstead, M. M.; Power, P. P. Synthesis and Characterization of the Monomeric Diaryls $\mathrm{M}\left\{\mathrm{C}_{6} \mathrm{H}_{3}-2,6-\mathrm{Mes}_{2}\right\}_{2}\left(\mathrm{M}=\mathrm{Ge}, \mathrm{Sn}\right.$, or Pb; Mes ) 2,4,6- $\left.\mathrm{Me}_{3} \mathrm{C}_{6} \mathrm{H}_{2-}\right)$ and Dimeric Aryl-Metal Chlorides $\left[\mathrm{M}(\mathrm{Cl})\left\{\mathrm{C}_{6} \mathrm{H}_{3}-\right.\right.$ 2,6-Mes 2$\}]_{2}(\mathrm{M}=\mathrm{Ge}$ or Sn). Organometallics 1997, 16, 1920-1925.

(48) Matsumoto, T.; Nakaya, Y.; Tatsumi, K. Synthesis of Oxo- and Sulfido-Bridged Germanium-Ruthenium Complexes and Reactions on the Chalcogenido Bridges. Organometallics 2006, 25, 4835-4845. 
(49) Nie, P.; Yu, Q.; Zhu, H.; Wen, T.-B. Ruthenium and Osmium Germyl Complexes Derived from the Reactions of $\mathrm{MXCl}\left(\mathrm{PPh}_{3}\right)_{3}(\mathrm{M}=\mathrm{Ru}$, Os; $\mathrm{X}=\mathrm{Cl}, \mathrm{H})$ with Terphenylchlorogermylene $\left(\mathrm{C}_{6} \mathrm{H}_{3}-2,6\right.$-Trip 2$) \mathrm{GeCl}($ Trip $=2,4,6-$ ${ }^{i} \mathrm{Pr}_{3} \mathrm{C}_{6} \mathrm{H}_{2}$ ). Eur. J. Inorg. Chem. 2017, 4784-4796.

(50) Moreno, J. J.; Espada, M. F.; Krüger, E.; López-Serrano, J.; Campos, J.; Carmona, E. Ligand Rearrangement and Hemilability in Rhodium(I) and Iridium(I) Complexes Bearing Terphenyl Phosphines, Eur. J. Inorg. Chem. 2018, 2309-2321.

(51) Henoch, J.; Auch, A.; Diab, F.; Eichele, K.; Schubert, H.; Sirsch, P.; Block, T.; Pöttgen, R.; Wesemann, L. Cyclic Distannene or Bis(stannylene) with a Ferrocenyl Backbone: Synthesis, Structure, and Coordination Chemistry. Inorg. Chem. 2018, 57, 4135-4145. (52) García, J. M.; Ocando-Mavárez, E.; Kato, T.; Coll, D. S.; Briceño, A.; Saffon-Merceron, N.; Baceiredo, A. Synthesis and Characterization of Rhodium Complexes with PhosphineStabilized Germylenes. Inorg. Chem. 2012, 51, 8187-8193.

(53) Álvarez-Rodríguez, L.; Cabeza, J. A.; Fernández-Colinas, J. M.; García-Álvarez, P.; Polo, D. Amidinatogermylene Metal Complexes as Homogeneous Catalysts in Alcoholic Media. Organometallics 2016, 35, 2516-2523.

(54) Álvarez-Rodríguez, L.; Brugos, J.; Cabeza, J. A.; García-Álvarez, P.; Pérez-Carreño, E.; Polo, D. Synthesis and initial transition metal chemistry of the first PGeP pincer-type germylene. Chem. Commun. 2017, 53, 893-896. (55) Brugos, J.; Cabeza, J. A.; García-Álvarez, P.; Pérez-Carreño, E. From a PGeP Pincer-Type Germylene to Metal Complexes Featuring Chelating (Ir) and Tripodal (Ir) PGeP Germyl and Bridging (Mn2) and Chelating (Ru) PGeP Germylene Ligands. Organometallics 2018, 37, 1507-1514.

(56) Campos, J. Bimetallic cooperation across the periodic table, Nat. Rev. Chem. 2020, 4, 696-702.

(57) Tate, B. K.; Wyss, C. M.; Bacsa, J.; Kluge, K.; Gelbauma, L.; Sadighi, J. P. A dinuclear silver hydride and an umpolung reaction of CO2 Chem. Sci. 2013, 4, 3068-3074.

(58) Khairallah, G. N.; O’Hair, R. A. J. Gas phase synthesis and reactivity of Agn+ and Agn-1H+ cluster cations Dalton Trans., 2005, $2702-2712$.

(59) Espada, M. F.; Campos, J.; López-Serrano, J.; Poveda, M. L.; Carmona, E. Methyl-, Ethenyl-, and EthynylBridged Cationic Digold Complexes Stabilized by Coordination to a Bulky Terphenylphosphine Ligand. Angew. Chem. Int. Ed. 2015, 54, 15379-15384.

(60) Campos, J. Dihydrogen and Acetylene Activation by a Gold(I)/Platinum(0) Transition Metal Only Frustrated Lewis Pair. J. Am. Chem. Soc. 2017, 139, 2944-2947.

(61) Raţ, C. I.; Soran, A.; Varga, R. A.; Silvestru, C. C-H Bond Activation Mediated by Inorganic and Organometallic Compounds of Main Group Metals. Adv. Organomet. Chem. 2018, 70, 233-311

(62) Usher, M.; Protchenko, A. V.; Rit, A.; Campos, J.; Kolychev, E. L.; Tirfoin, R.; Aldridge, S. A systematic study of structure and E-H bond activation chemistry by sterically encumbered germylene complexes. Chem. Eur. J. 2016, $22,11685-11698$. 